\title{
Analysis of the performances of electric energy storage in residential applications
}

\author{
Antonio Gagliano*, Francesco Nocera \\ Dipartimento di Ingegneria Elettrica, Elettronica e Informatica, University of Catania, V.le A. \\ Doria 6, Catania 95125, Italy
}

Email: antonio.gagliano@dieei.unict.it

\begin{abstract}
The energy generation through photovoltaic systems has recorded extremely high growth rates. In Italy, more than 500,000 PV plants have been installed which produce almost 109,5 TWh, reaching a covering 5.6\% of the total energy demand. The fall in prices of technology has resulted in a sharp drop in the cost of generation photovoltaic energy, which based on current projections reach competitiveness with the energy purchased from the grid in the next future, giving rise to a possible further spread of PV plants. In recent years appeared unavoidable the need to address the issues arising from the uncontrolled growth of photovoltaic installations such as intermittent, loss of balance and predictability of the generation. A possible strategy that facilitates the integration of renewable energy is the usage of battery electric energy storage (EES), together with incentives for self-consumption or energy independence from the network. The stepwise reduction of remuneration for photovoltaic grid feed-in power in Italy, residential energy grid-interactive energy storage systems for buffering of surplus PV generation and subsequent self-consumption is a field of growing interest and market activity. The study aims to identify the energy exchange with the grid of combined PV-EEs systems dedicated to residential and small commercial photovoltaic generation plants.
\end{abstract}

Keywords: Electric Energy Storage, PV Plant, Renewable Energy, Energy Costs.

\section{INTRODUCTION}

Renewable energy sources (RES) such as solar and wind are expected to play a foremost role in mitigating climate change and resource depletion as well as domestic energy security.

Therefore, it is possible to prognosticate that the future energy supply will be strongly influenced by the energy produced by RES, which depends on local weather conditions and in some cases is limited to daytimes period [1].

As a consequence, the fluctuations of the energy generation generate considerable gaps between electricity consumption and supply. Such mismatches between demand and supply pose an increasing threat to the stability of the electricity system.

Thereby, a more widespread use of intermittent energy sources requires to balance the surplus and deficit in energy due to the strong and sudden fluctuations of the generation during the day and all over the year [2].

An effective resource for reducing the mismatches between supply and demand of energy by RES are storage technologies, both for large and small-scale applications.

Generally, the number of cycles and the period of the operation are used for defining the operative time of on-grid energy electricity storage (EES) systems.
EES with high cycle stability and short duration at high power output is requested for the maintenance of voltage quality (e.g. compensation of reactive power); on the other hand, longer storage duration and fewer cycles are required for time shifting [3].

In Italy, more than 500,000 PV plants have been installed which produces almost 109,5 TWh, reaching a covering 5.6\% of the total energy demand [4].

With the growing popularity of PV plant in residential building, the interest in batteries system, that could store electricity from those installations, is increasing. In the future, such storage systems could benefit homeowners, by giving them more control over how and when they obtain the power they need, while helping utilities by shifting demand to offpeak hours and smoothing out the load on the system.

An important role expected for electric energy storage (EES), in a self-consumption or zero-export scenario is to store excess local PV production and discharge the stored energy when necessary.

Thus, the EES allows the Energy Management Systems (EMS) to function optimally with less power needed from the grid. In the future, Smart Grid and Electric vehicles (EVs) will be not only a new load for electricity grid but they will be also a possible distributed energy resource able to provide a load- 
shifting function in a smart grid.

Typically, the effectiveness of EES for PV is investigated examining its potential to increase the share of electricity generated by PV residential system that is consumed by the household (self-consumption) [5]

Many studies are focused on potentiality of the sharing of electricity generated by Decentralized Energy Systems (DES) [6]. Gibson et al report on the optimization of charging efficiency from a PV system to a battery in a residential energy system [7]. Colmenar et al. indicate that storage technologies allow households to reduce the amount of electricity that is bought at retail prices and the one to be sold at wholesale prices [8].

Literature studies have advanced our awareness on the function that storage plays in residential PV systems. However, insufficient guidance is available to quantify the advantages of combining PV and storage systems to justify the requested extra costs.

Moreover, the feasibility of the electric storage has been investigated under the hypothesis of policy support in the form of feed-in tariffs and/or additional premiums for selfconsumed electricity [9].

Therefore, under the assumption of the reduction of policy incentives in the immediate future, the accurate chosen of the PV system and battery storage significantly affect the economic feasibility of the combined PV-battery system.

Indeed, the economic practicability of the electric storage is toughly dependent by the amount of electricity produced that is self-consumed [10].

The aim of this paper is to investigate the grade of selfsufficiency and the energy exchanged with the grid for different scenarios of residential PV systems combined with battery storage.

More specifically, three size of PV plant, $(2.4,3.1$ and 3.8 $\mathrm{kWp})$ and annual household consumptions (3,000, 4,000 and $5,000 \mathrm{kWh}$ ) have been investigated for defining the performances of each of the nine proposed combinations [4].

The results of this study provide useful information for policy making and the trend toward distributed electricity generation.

\section{MATERIAL AND METHODS}

\subsection{Electricity storage}

A battery is a device that allows to convert chemical energy into electrical energy and vice versa.

The main battery characteristics are:

- Capacity (C), measured in Ampere-hour (Ah), indicates the theoretical value of the intensity of current that the battery is able to provide for a process of discharge of one-hour durations.

- Stored energy ( $\left.E_{\mathrm{EES}}\right)$, measured in Watt-hours (Wh), indicates the amount of energy stored in the battery and it is given by the integral value of the capacity of the product to the average discharge voltage.

- State of Charge (SOC) identifies the remaining capacity of a battery $(0 \%=$ empty; $100 \%=$ full $)$ and it is a function of the load current and the operating temperature.

- Depth of Discharge (DOD) describes how deeply the battery is discharged $(100 \%=$ empty; $0 \%=$ full $)$.

- Discharge voltage (Cut-off Voltage), is the minimum allowable voltage, generally defines the "empty" state of the battery.

- Life cycles is the number of charge-discharge cycles to which a battery can be subjected up to a specific DOD value (typically 80\%) before they manifest a degradation of its performance.

The operating life of a battery is deeply affected the amplitude of the charge and discharge cycles, the DOD and other operational conditions such as the temperature.

The temperature within the cell increases with the applied current for ohmic effect, but it may increase considerably during the charge to the overrun of $80-90 \%$ of the SOC due to parasitic reactions of electrolyte degradation [11].

In order to preserve the normal aging of the same battery, the SOC is typically maintained in a range between $20 \%$ and $90 \%$ and the maximum values of DOD stood at around $70 \%$.

Typically, the higher is the DOD of a battery; the lower is the number of life cycles.

Specific parameters, such as specific energy and specific power, referred to the weight of the system and expressed respectively in $\mathrm{Wh} / \mathrm{kg}$ and $\mathrm{W} / \mathrm{kg}$ are to compare different systems [12].

Nowadays, the most used technologies for the electrochemical accumulators are Lead Acid battery (LA), Nickel Cadmium (NiCd), Nickel Metal Hydride battery NiMH), Litio-ione (Li-ion), Sodium Nickel Chloride (Ni$\mathrm{NaCl})$, etc.

LA batteries are the most widely used battery type; they represent a mature technology at low cost. Their main disadvantage is that the usable capacity decreases when high power is discharged. Typical service life is 6 to 15 years with a cycle life of 1,500 cycles at $80 \%$ depth of discharge. Typical coulombic charge efficiency can be as high as $85 \%$ to $90 \%$.

Power density and the number of cycles of nickel-based batteries compared with lead acid batteries are higher moreover energy density is slightly greater. They have been prohibited for consumer use because of the toxicity of cadmium.

$\mathrm{NiMH}$ batteries have similar characteristics to $\mathrm{NiCd}$ batteries, except for the maximal nominal capacity that is ten times less than NiCd and LA. Otherwise, they have much higher energy densities.

Li-ion batteries have the advantage of a high gravimetric energy density, and the prospective of large cost reductions through mass production. Li- ion batteries generally have an efficiency, typically in the range of $95 \%-98 \%$.

Safety is a grave issue in lithium ion battery technology. Indeed, most of the metal oxide electrodes are thermally unstable and can decompose at elevated temperatures, releasing oxygen, which can lead to a thermal runaway.

To minimize this risk, lithium ion batteries are equipped with a Battery Management System (BMS) to avoid overcharging and over discharging. Usually a voltage balance circuit is also installed to monitor the voltage level of each individual cell and prevent voltage deviations among them.

The Li-ion technology is by far the favored than the other. The lithium, being the lightest metal (equivalent weight: 6.94 $\mathrm{g} \mathrm{mol}^{-1}$ ) and the more electropositive, possesses a high specific capacity equivalent of about $3.8 \mathrm{Ah}$ g- 1 .

The life cycle can be used to measure the life of Li-ion batteries deployed in EES applications for solar photovoltaic installations. It is expressed in terms of the number of charge and discharge cycles that can be achieved depending to what level the battery is discharged - its 'depth of discharge' or 
DOD. It is influenced by both the DOD and the charging rate.

Figure 1 shows the expected life for Li-ion cells for a capacity loss of $20 \%$ in function of the temperature.

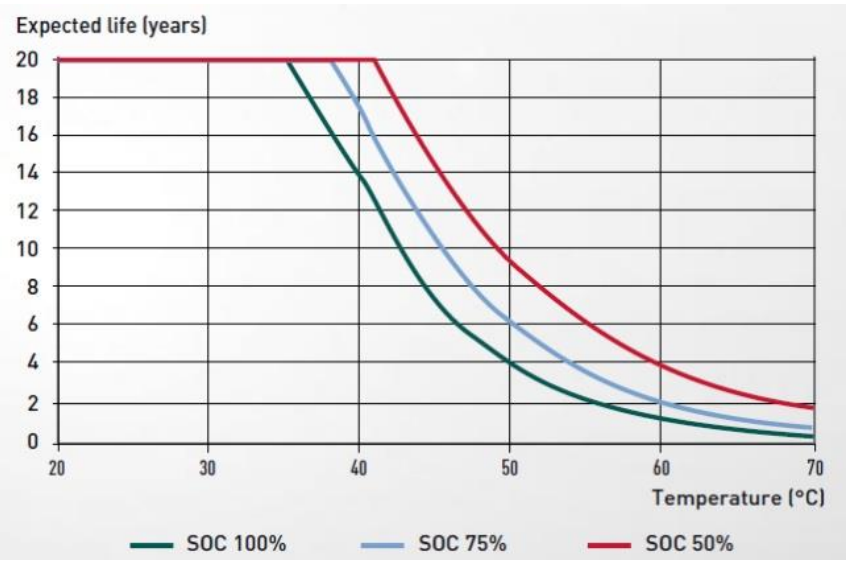

Figure 1. Expected life for Li-ion cells [13]

\subsection{Electricity generation}

The PV electricity production ( $\left.\mathrm{E}_{\mathrm{PV}}\right)$ is a function of the global solar irradiation $(G)$, the outside air temperature and the performance characteristics of the PV module as well as the angles of tilt, orientation and the area of PV modules (APV).

The energy yield from the PV modules has been calculated through a simplified approach as in the follows [14].

$E_{P V}=A_{P V} \cdot G \cdot \eta_{P V} \cdot \eta_{i n v} \cdot \eta_{m}$

$\eta_{P V}=\eta_{S T C} \cdot\left[1+\mu \cdot\left(T_{P V}-25\right)+0.12 \cdot \ln \left(\frac{G}{1000}\right)\right]$

$T_{P V}=T_{a}+\left(\frac{N O C T-20}{800}\right) \cdot G \cdot\left(1-\frac{\eta_{S T C}}{\tau \alpha}\right)$

The calculation of the electricity production $E_{P V}$ is performed on a time basis $\Delta \mathrm{t}=15 \mathrm{~min}$. In Eq. (1), $\eta_{\mathrm{PV}}$ conversion efficiency of the PV cells, $\eta_{\text {inv }}=0.95$ is the efficiency of the inverter and $\eta_{\mathrm{m}}=0.92$ accounts for the losses due to mismatch. The degradation of PV panels and the small decrease of resulting power is neglected.

As well known the conversion efficiency of the PV cells (Eq. $2)$ is a function of the temperature of the PV cells $\left(\mathrm{T}_{\mathrm{PV}}\right)$ [15], which is in turn a function of the operating conditions (Eq.3).

$\mathrm{T}_{\mathrm{NOCT}}$ is the nominal operating cell temperature, defined as the temperature reached by open circuited cells in a module under the follows conditions: absence of electrical load, total irradiance of $800 \mathrm{~W} / \mathrm{m}^{2}$, ambient temperature of $20^{\circ} \mathrm{C}$ and wind speed of $1.0 \mathrm{~m} / \mathrm{s}$ [16]. The value of $\mathrm{T}_{\text {NOCT }}$ is provided in the technical data sheet of the PV module. The terms " $\tau_{\mathrm{v}} \alpha$ " accounts for the transparency of the front glass [17]

\subsection{Electric load profile}

During the day, the load profile is influenced by the characteristic of the domestic appliances and the user habits.

In this study, a standard load profile of electricity consumption for Italian household in Italy with a resolution of 15 minutes has been used $[18,19]$.

\section{SIMULATION MODEL}

The battery is modelled with a simplified approach, considering a constant efficiency of $95 \%$. Thus, the effects of the discharging power, the temperature and the battery age have been neglected.

With the aim to maximize the life of the storage system, the maximum depth of discharge has been limited to the $10 \%$ of the maximum capacity $\mathrm{SOC}_{\max }$

The PV electricity output (EPV) that instantly can be consumed by the load ( $\left.\mathrm{E}_{\mathrm{h}-\mathrm{load}}\right)$ is used directly on-site.

In the case in which the PV power exceeds the load, a surplus occurs. As long as the battery does not reach the maximum state of charge $\left(\mathrm{SOC}_{\max }\right)$, the excess $\mathrm{PV}$ power is used for charging the battery ( $\left.\mathrm{E}_{\mathrm{EES}}\right)$. Otherwise, the surplus PV power is driven to the grid ( $\left.\mathrm{E}_{\text {grid-exp}}\right)$. When the load exceeds the generated PV power, the battery is discharged until the minimum state of charge is reached. The grid (Egrid-imp) supplies the remaining load.

Therefore, different scenarios can occur.

Case A: the PV power exceeds the load, therefore a surplus $(\mathrm{S})$ occurs: $(\operatorname{EPV}(\tau)>$ Eh-load $(\tau))$

As long as the battery does not reach the maximum state of charge $\left(\mathrm{SOC}_{\max }\right)$ the resulting excess $\mathrm{PV}$ power will be used for charging the battery (S1), restricted by the battery inverter power. Otherwise, the surplus PV power will be fed into the grid (S2).

Subcase S1. The battery is able to accept the whole surplus $\left(E_{\text {grid-exp }}=0\right)$, that is:

$\mathrm{E}_{\mathrm{EES}}(\tau-\mathrm{d} \tau)+\left(\mathrm{E}_{\mathrm{PV}}(\tau)-\mathrm{E}_{\mathrm{h}-\mathrm{load}}(\tau)\right)<\mathrm{SOC}_{\max }$

Then, the energy stored in the battery will be:

$\mathrm{E}_{\mathrm{EES} \_c h}(\tau)=\left(\mathrm{E}_{\mathrm{PV}}(\tau)-\mathrm{E}_{\mathrm{h}-\mathrm{load}}(\tau)\right) \cdot \eta_{\mathrm{ch}}$

Subcase S2. The battery is unable to accept the whole surplus, that is:

$\mathrm{E}_{\mathrm{EES}}(\tau-\mathrm{d} \tau)+\left(\mathrm{E}_{\mathrm{PV}}(\tau)-\mathrm{E}_{\mathrm{h}-\text { load }}(\tau)\right)>\mathrm{SOC}_{\max }$

Therefore, the surplus $(\operatorname{EPV}(\tau)-\operatorname{Eh}-\operatorname{load}(\tau))$ is partially reversed to the battery:

$\mathrm{E}_{\mathrm{EES} \_\mathrm{ch}}(\tau)=\left(\mathrm{SOC}_{\max }-\mathrm{E}_{\mathrm{EES}}(\tau)\right) \cdot \eta_{\mathrm{ch}}$

and the remaining surplus is driven to the grid $\left(\mathrm{E}_{\text {grid-exp }}(\tau)\right)$ :

$\mathrm{E}_{\text {grid-exp }}(\tau)=\left(\mathrm{E}_{\mathrm{PV}}(\tau)-\mathrm{E}_{\mathrm{h}-\text { load }}(\tau)\right)-\left(\mathrm{SOC}_{\max }-\mathrm{E}_{\mathrm{EES}}(\tau)\right) \eta_{\mathrm{ch}}$

Case B. The house electric load exceeds the generated PV power, therefore a deficit occurs: $E_{P V}(\tau)<\operatorname{Eh}-\operatorname{load}(\tau)$

To compensate the emerging deficit (D), the electricity stored within the battery or the energy imported from the grid can be exploited. The battery is discharged up to the minimum state of charge is touched. The remaining load is covered by energy drawn from the grid.

Two different possibilities emerge: the electricity consumption can be either entirely satisfied by the stored energy within the battery, (D1), or not (D2).

Subcase D1. Electricity consumption entirely satisfied by the stored energy within the battery. 
$\mathrm{E}_{\mathrm{EES}}(\tau-\mathrm{d} \tau)+\left(\mathrm{E}_{\mathrm{PV}}(\tau)-\mathrm{E}_{\mathrm{h}-\mathrm{load}}(\tau)\right)>\mathrm{DOD} \cdot \mathrm{SOC}_{\max }$

Therefore, the energy stored in the battery is reduced by the quantity:

$\mathrm{E}_{\mathrm{EES}}(\tau)=\mathrm{E}_{\mathrm{EES}}(\tau-\mathrm{d} \tau)+\left(\mathrm{E}_{\mathrm{PV}}(\tau)-\mathrm{E}_{\mathrm{h}-\mathrm{load}}(\tau)\right) / \eta_{\mathrm{dis}}$

Subcase D2. The electricity consumption can not be entirely satisfied by the stored energy within the battery, that is:

$\mathrm{E}_{\mathrm{EES}}(\tau-\mathrm{d} \tau)+\left(\mathrm{E}_{\mathrm{PV}}(\tau)-\mathrm{E}_{\mathrm{h}-\mathrm{load}}(\tau)\right)<\mathrm{DOD} \cdot \mathrm{SOC}_{\max }$

Therefore, the house load $\left(\mathrm{E}_{\text {house-load }}(\tau)\right)$ is partially provided by the battery:

$\left(\mathrm{E}_{\mathrm{EES}}(\tau)-\mathrm{DOD} \times \mathrm{SOC}_{\max }\right) / \eta_{\mathrm{dis}}$

The remaining $\mathrm{E}_{\mathrm{h}-\text { load }}(\tau)$ is supplied by the grid $\mathrm{E}_{\text {grid-imp }}(\tau)$

$\mathrm{E}_{\text {grid-imp }}(\tau)=\mathrm{E}_{\mathrm{EES}}(\tau) / \eta_{\text {dis }}+\left(\mathrm{E}_{\mathrm{PV}}(\tau)-\mathrm{E}_{\mathrm{h}-\mathrm{load}}(\tau)\right)-\mathrm{DOD} \cdot \mathrm{SOC}_{\max }$

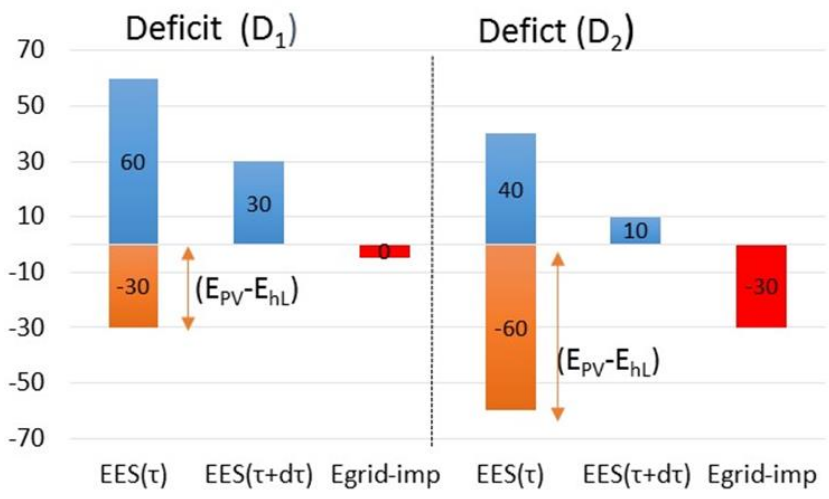

Figure 2. Example of deficit scenario

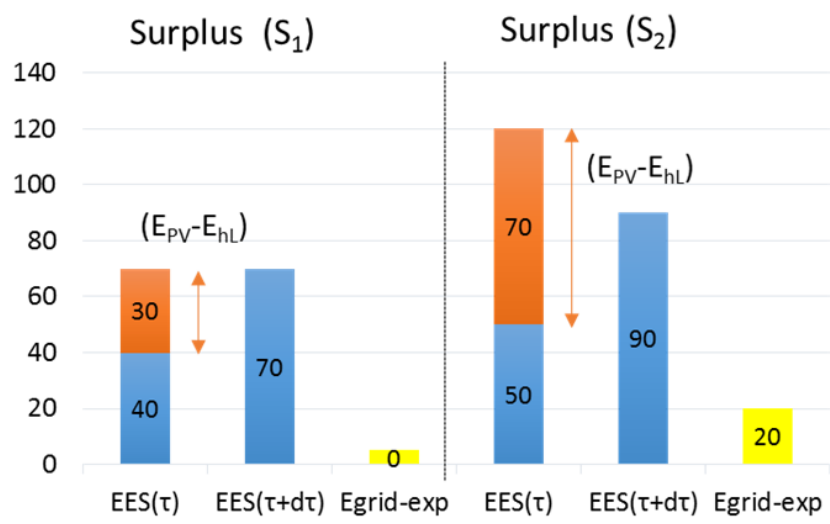

Figure 3. Example of surplus scenario

To evaluate the simulation results, the following assessment criteria were also calculated [20].

The realised self-consumption rate (Rsc), which is defined by the ratio between the PV energy, which is, used directly Ehload_sc (self-consumption) or used for charging the battery EEES_ch and the overall produced PV energy:

$\operatorname{Rsc}=\left(\mathrm{E}_{\mathrm{h} \_ \text {load_sc }}+\mathrm{E}_{\mathrm{EES} \_ \text {ch }}\right) / \boldsymbol{\Sigma} \mathrm{E}_{\mathrm{PV}}$
The degree of self-sufficiency (Dss) describes the share of the load consumption that is supplied by the PV battery system, it is calculated by the ratio between the directly used PV energy $E_{h \_ \text {load-sc }}$, the energy discharged from the battery $\mathrm{E}_{\mathrm{EES}-\mathrm{dis}}$ and the load demand $\mathrm{E}_{\mathrm{h}-\mathrm{load}}$.

Dss $=\left(E_{h_{-} \text {load-sc }}+E_{\text {EES-dis }}\right) / E_{\text {h-load }}$

\section{DESCRIPTION OF SIMULATION SCENARIOS}

The baseline scenario is a PV-household with a lithiumbased battery system with a capacity of $6.4 \mathrm{kWh}$. The specifications of the PV-EES system are shown in Table 1.

Table 1. Specifications of the PV-EES system

\begin{tabular}{|cc|}
\hline ITEM & VALUE \\
\hline Power, continuous and peak & $3.3 \mathrm{~kW}$ \\
Energy & $6.4 \mathrm{kWh}$ \\
Internal Battery Voltage & $<50 \mathrm{VDC}$ \\
System Operating Voltage & $350 \mathrm{~V}-450 \mathrm{~V}$ \\
Voltage in OFF State & $0 \mathrm{VDC}$ \\
Current & $9.5 \mathrm{ADC}$ \\
Round Trip Efficiency & $92.5 \%$ (for a $400 \mathrm{~V}-450 \mathrm{~V} \mathrm{DC}$ \\
(Beginning of Life) & bus) \\
Depth of Discharge & $100 \%$ \\
\hline
\end{tabular}

Residential PV battery systems can be discriminated in the connection of the battery between DC and AC coupled systems [20]. In this study, a DC coupled residential PV battery systems has been investigated (Fig. 4)

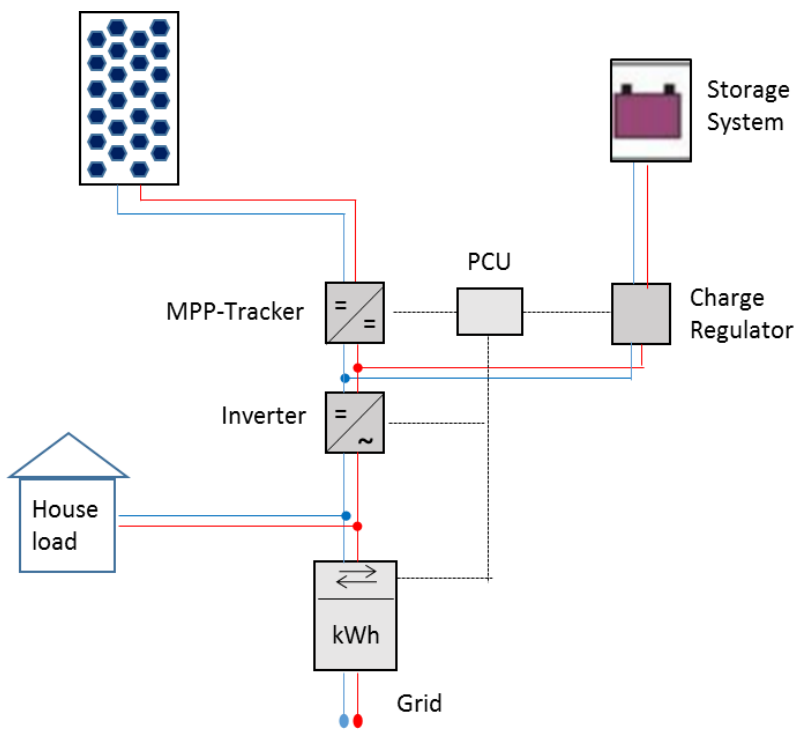

Figure 4. Configuration of the PV battery systems

As regard the electric consumption, three annual values have been chosen $(3,000,4,000$ e $5,000 \mathrm{kWh} /$ year $)$, which replicate the most diffused percentages of household consumption in Italy [4] have been examined.

However, the annual electricity consumption can be also obtained through building numerical simulation [21].

This battery size the storage allows to achieve about 245 equivalent full cycles (EFC) in one year summing up about $3650 \mathrm{EFC}$ over the depreciation period of 15 years. 
The operation strategy used in this study estimates a maximum possible self-consumption: the energy storage will store all power produced by the PV system, which exceeds consumption. As such, a larger battery capacity leads to higher rate of self-consumption.

The EES is charged via the control unit (PCU) from either the grid or the PV, as well as the electricity demand can be supplied either by the grid or by the PCU.

The state of charge of the battery is restricted to a range between $10 \%$ and $90 \%$ of the nominal battery capacity.

Therefore, only a share of $80 \%$ of the installed battery capacity is usable. The losses of the battery inverter are considered with a constant efficiency factor of $95 \%$. This implies that the power dependent losses of the battery converter are not taken into account.

\subsection{Specifications of PV plant}

The peak power of the photovoltaic plant ranges between $2.4,3.1$ and $3.8 \mathrm{kWp}$. The different scenarios which arise are characterized by ratios between electric generation and electric consumption between 1.0 to 2.0. The nominal characteristics of the PV modules are reported in table 2.

Table 2. Nominal characteristics of the PV modules

\begin{tabular}{|cc|}
\hline ITEM & VALUE \\
\hline PSTC $[\mathrm{W}]$ & $240 \mathrm{~W}$ \\
APV $\left[\mathrm{m}^{2}\right]$ & 1.46 \\
$\eta_{\mathrm{STC}}[\%]$ & 16.28 \\
$\mathrm{~T}_{\mathrm{NOCT}}$ & $43.6^{\circ} \mathrm{C}$ \\
$\mu\left[\% /{ }^{\circ} \mathrm{C}\right]$ & -0.42 \\
\hline
\end{tabular}

The PV modules have a southward orientation and a tilt of $18^{\circ}$, which corresponds to the most diffuse inclination of the tilted roofs in the south of Italy [22, 23]. Fifteen minutes' solar irradiation data for Catania ( $37^{\circ}$ lat, $15^{\circ} \mathrm{long}$ ), Italy, was obtained from the database PV-GIS (Photovoltaic Geographical Information System) [24].

In figure 5, the monthly horizontal and the tilted irradiation $\left(\beta=18^{\circ} \mathrm{C}\right)$ are depicted

Figures 6 and 7 show the fifteen minutes' variation of the $\mathrm{PV}$ energy generation $\left(\mathrm{E}_{\mathrm{PV}}\right)$, the electric building load (Ehload), the battery energy stored ( $\left.\mathrm{E}_{\mathrm{EES}}\right)$ as well as the imported, and or the exported energy by the grid, for the $3.1 \mathrm{kWp} \mathrm{PV}$ plant, 3,000 kWh of house load consumption respectively in December and June.

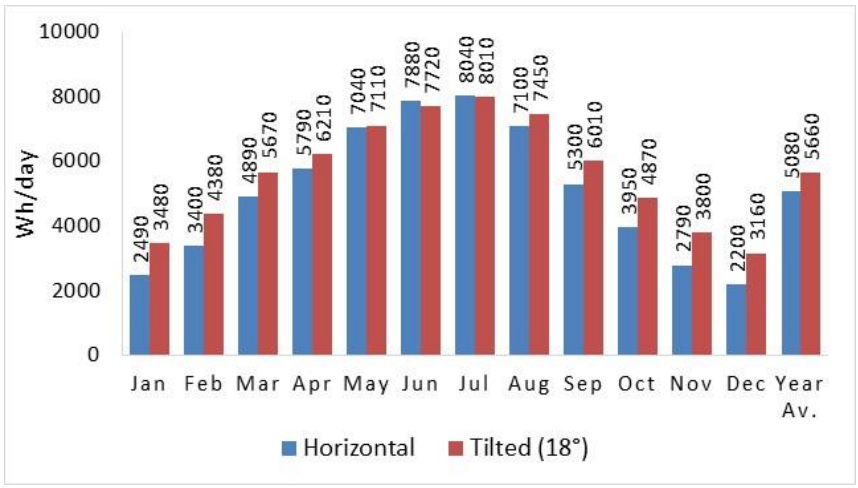

Figure 5. Horizontal and tilted solar irradiation
Starting from these data the energies generated, for each of the three sizes of photovoltaic plants investigated, have been calculated with a time step of $15 \mathrm{~min}$, through the previous equations (1, 2 and 3).

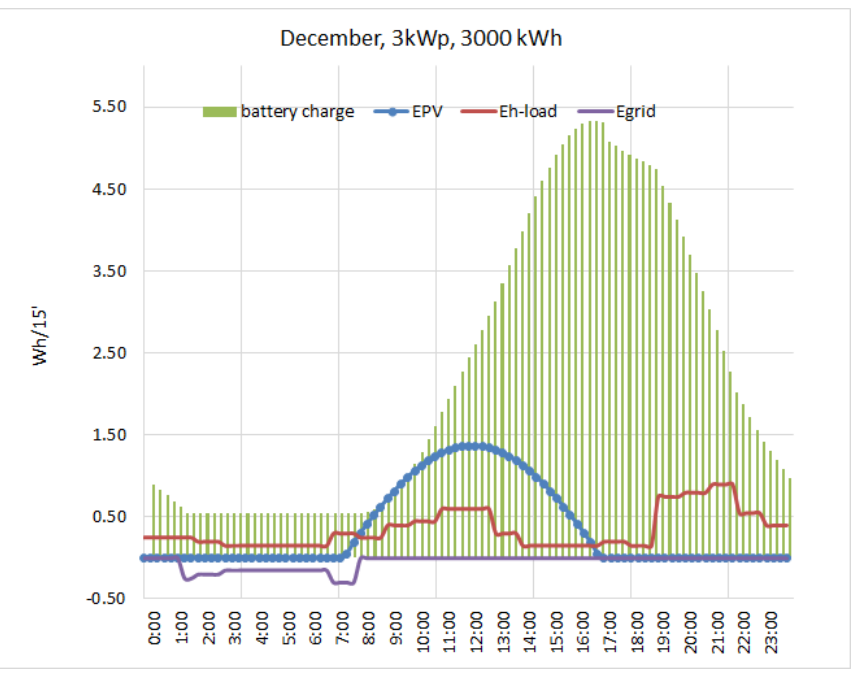

Figure 6. Energy daily variation (December)

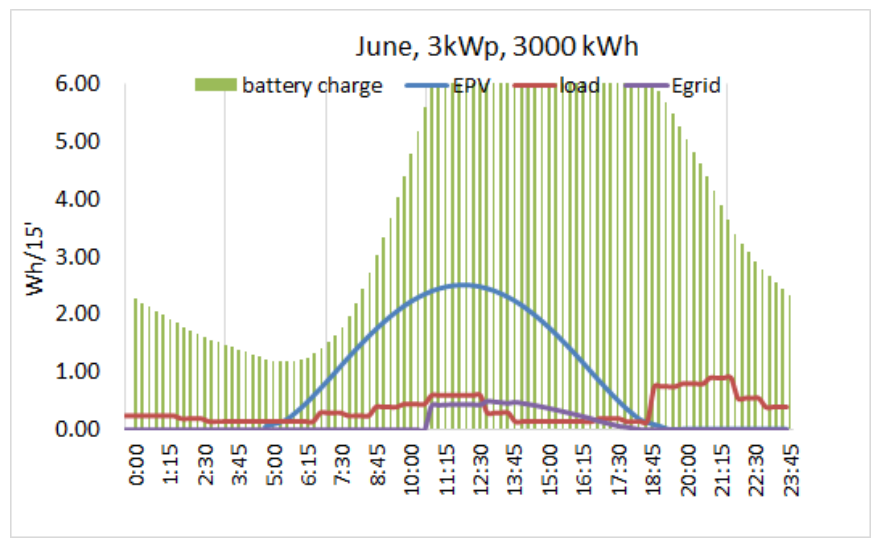

Figure 7. Daily Energy balance(June)

It becomes evident that without the energy storage system is limited to the intersection between the $E_{P} V$ and the $E_{h \_l o a d}$ curves. Otherwise the EES allows a huge reduction of the energy exchange with the grid. In the previous examples a deficit occurs in December and a surplus in June.

\section{RESULTS AND DISCUSSION}

\subsection{System energy balance}

In this study, the electric building load has been considered constant during all the year, therefore the differences in consumption during winter and summer season have been neglected.

However, the variation during the year of the amount of energy self-consumed ( $\left.\mathrm{E}_{\mathrm{h} \_ \text {load-sc }}\right)$ has been taken in account in function of the different extension of the period of irradiation.

Figure 8 shows the monthly variation of the PV energy generation $\left(\mathrm{E}_{\mathrm{PV}}\right)$, the self-consumed electric building load $\left(\mathrm{E}_{\mathrm{h}}\right.$ load-sc $)$, the battery energy stored $\left(\mathrm{E}_{\mathrm{EES} \_\mathrm{ch}}\right)$ as well as the imported, and or the exported energy by the grid, for 3,000 
$\mathrm{kWh}$ of house load consumption and the $3.1 \mathrm{kWp}$ size of PV plant.

$P_{\mathrm{PV}}=3.1 \mathrm{kWp} ; E_{\mathrm{HL}}=3,000 \mathrm{kWh}$

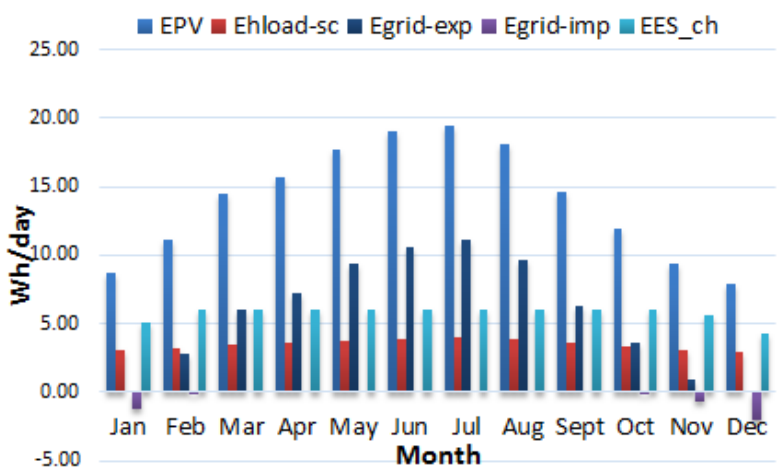

Figure 8. Monthly energy balance

It is evident that this combination between PV energy generation, house consumptions and battery size allows to almost zero the energy imported by the grid.

Moreover, figures 9, 10 and 11 summarize the annual energy balance for the different combinations of PV energy generation, house consumptions and battery size.

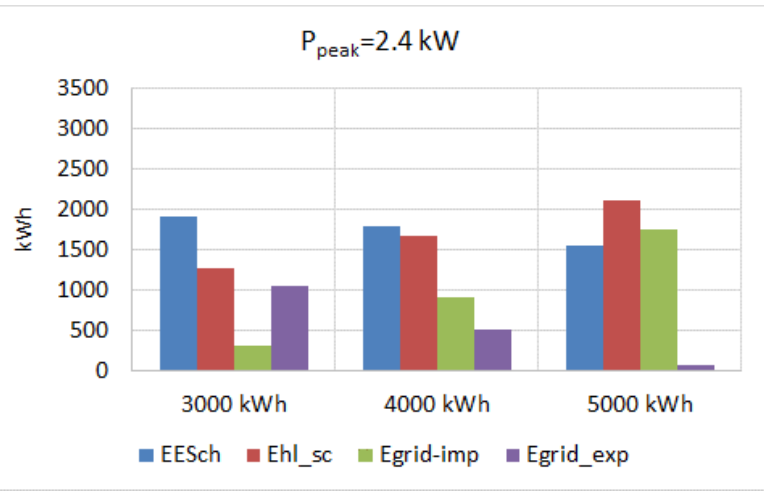

Figure 9. Yearly energy balance $(\mathrm{P}=2.4 \mathrm{kWp})$

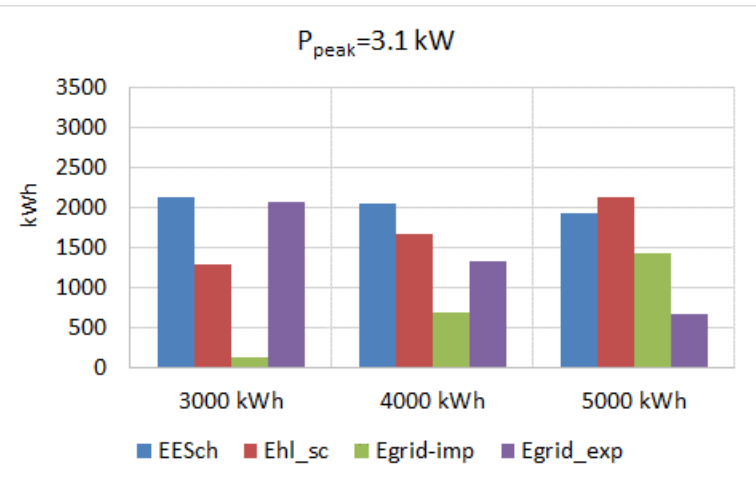

Figure 10. Yearly energy balance $(\mathrm{P}=3.1 \mathrm{kWp})$

The analysis of the developed simulations allows to observe that all the examined configurations needs to import energy from the grid, ranging by $43.40 \mathrm{kWh}$ to $1,754.27 \mathrm{kWh}$.

The amount energy self-consumed $\left(E_{h l-s c}\right)$ is quite independent by the PV plant size and increase with the growth of the building energy consumptions. The energy stored in the EES ( $\left.E_{E S \_c h}\right)$ is slightly affected by of both the PV plant size and the building energy consumptions.

The previous results are not confirmed in the scenarios with the highest energy requests $(5,000 \mathrm{kWh})$ and the lowest size of the PV plant $(2.4$ and $3.1 \mathrm{kWp})$, which are certainly under dimensioned in such cases.

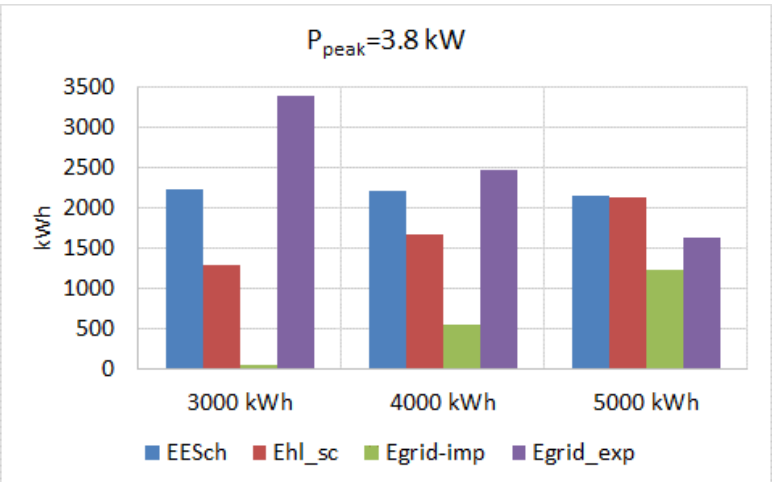

Figure 11. Yearly energy balance $(\mathrm{P}=3.8 \mathrm{kWp})$

As consequence, the energy exchanged with the grid, imported and exported is highly variable in function of the PV plant size and the amount of the energy consumption.

The energy exchange is almost balanced in the configurations $2.4 / 3,000$ and $3.8 / 5,000 \mathrm{kWp} / \mathrm{kWh}$, with a difference less than $410 \mathrm{kWh}$.

Otherwise, the minimum energy exchange with the grid is achieved in the configuration $2.4 / 3,000 \mathrm{kWp} / \mathrm{kWh}$.

Finally, the two parameters self-consumption rate $\left(\mathrm{R}_{\mathrm{sc}}\right)$ and the degree of self-sufficiency $\left(\mathrm{D}_{\mathrm{ss}}\right)$ has been calculated.

Figure 12 depicts the variations of the previously introduced assessment criteria's in function of both the PV plant sizes and the yearly energy consumptions.

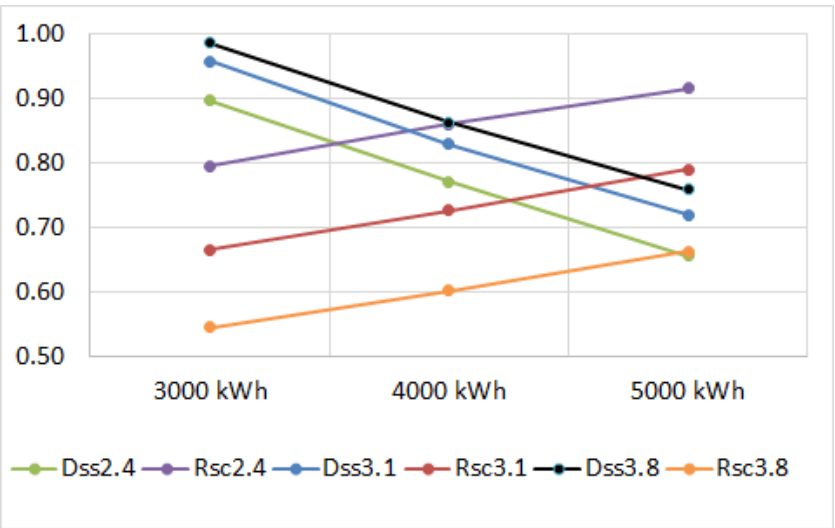

Figure 12. Assessment criteria $D_{s s}$ and $R_{s c}$

As regard the self-consumption ratio $\left(\mathrm{R}_{\mathrm{sc}}\right)$, it grows in harmony with the increase of the energy needs and assumes the highest value $(91.5 \%)$ when the size of the PV plant is lowest. Otherwise, the degree of self-sufficiency $\left(D_{s s}\right)$ shows an inverse behavior, it grows with the decrease of the energy needs and assumes the highest value $(98.5 \%)$ when the size of the PV plant is the highest.

The self-consumption ratio of the PV plants not associated with an EES system, under the selfsame combinations examined, shows the same behavior of the PV-EEs system.

Indeed, it grows in harmony with the increase of the energy needs and assumes the highest value (52.7\%) when the size of the PV plant is lowest. As regard the degree of self-sufficiency 
it shows a constant value of $\left(D_{\mathrm{ss}}=41.7 \%\right)$.

It is evident that a combined PV-EES system increases significantly the self-sufficiency of the household PV plant. However, this analysis does not take in account of the amount of the energy exchange with the grid.

This aspect is of fundamental prominence for evaluating the economic viability of the combined PV-EES system.

It becomes evident that the economic viability of such systems is highly dependent by the different prices between the energy imported or exported by the grid, as well as by the prices of the EES systems.

Thereby, a future development of this study will consist in the examination of the economic feasibility of the combined PV-EEs system.

\section{CONCLUSIONS}

The results reported in this paper suggest that the adoption of an energy electric storage system in PV plant is undoubtedly a suitable strategy to significantly increase the self-sufficiency of the household PV plant.

In any case, the results presented in this study are limited to the chosen size of the EES, which ranges from 1.5 to 2.0 times the annual electric consumption, as well as the ratios electric generation and electric consumption which ranges by 1.0 to 2.0. However, the field of investigation is reasonably wide for providing useful information for the most diffused size of residential PV plants.

As regard the rate of self-consumption and the degree of self-sufficiency $\left(D_{s s}\right)$ the combined PV - EES systems allow reaching value higher than $90 \%$.

That are of about two times the target obtainable by PV plant without EES system, under the selfsame combinations examined.

However, the analysis proposed in this study does not investigated the economic aspect related with the installation of these systems. Economic feasibility that is highly dependent by the different prices between the energy imported or exported by the grid, as well as by the prices of the EES systems.

Future development of this study will consist in the analysis of the financial feasibility of the combined PV-EEs system.

\section{REFERENCES}

[1] Tina G.M., Grasso A.D., Gagliano A. (2015). Monitoring of solar cogenerative PVT power plants: Overview and a practical example, Sustainable Energy Technologies and Assessments, Vol. 10, pp. 90-101. DOI: $10.1016 /$ j.seta.2015.03.007

[2] Eltawil M.A., Zhao Z. (2010). Grid-connected photovoltaic power systems: Technical and potential problems - A Review, Renewable and Sustainable Energy Reviews, Vol. 14, pp. 112-129. DOI: $\underline{10.1016 / j . r s e r .2009 .07 .015}$

[3] International Electrotechnical Commission. IEC. White paper Electricity energy storage, from http://www.iec.ch/whitepaper/energystorage/, accessed on 22 August. 2017.

[4] Terna. Analisi sintetica dei dati elettrici più rappresentativi dell'anno (2015) from http://download.terna.it/terna/0000/0901/75.PDF accessed on 22. August. 2017.

[5] Naumann M., Karl R.C., Truong C.N., Jossen A., Hesse H.C. (2015). Lithium-ion battery cost analysis in PVhousehold application, Energy Procedia, Vol. 73, pp. 37-47. DOI: $10.1016 /$ j.egypro.2015.07.555

[6] Fichera A., Frasca M. Volpe R. (2016) On energy distribution in cities: A model based on complex networks. International Journal of Heat and Technology, Vol. 34, pp. S430-S434. DOI: $\underline{10.18280 / \text { ijht. } 340409}$

[7] Gibson L.T., Kelly A.N. (2010). Solar photovoltaic charging of lithium-ion batteries, J. Power Sources, Vol. 195, pp. 3928-3932. DOI: 10.1016/j.jpowsour.2009.12.082

[8] Colmenar-Santos A., Campíñez-Romero S., PérezMolina C., Castro-Gil M. (2012). Profitability analysis of grid-connected photovoltaic facilities for household electricity self-sufficiency, Energy Policy, Vol. 51, pp. 749-764. DOI: $10.1016 /$ j.enpol.2012.09.023

[9] Hoppmann J., Volland J., Schmidt T.S., Hoffmann V.H. (2014). The economic viability of battery storage for residential solar photovoltaic systems - a review and a simulation model", Renewable and Sustainable Energy Reviews, Vol. 39, pp. 1101-1118. DOI 10.1016/j.rser.2014.07.068

[10] Watanabe S., Kinoshita M., Hosokawa T., Morigaki K., Nakura K. (2014). Capacity fading of LiAlyNi1-x-yCoxO2 cathode for lithium-ion batteries during accelerated calendar and cycle life tests, Journal of Power Sources, Vol. 260, pp. 50-56. DOI: 10.1016/j.jpowsour.2014.02.103

[11] Watanabe S., Kinoshita M., Hosokawa T., Morigaki K., Nakura K. (2014). Capacity fading of LiAlyNi1-x-yCoxO2 cathode for lithium-ion batteries during accelerated calendar and cycle life tests, Journal of Power Sources, Vol. 260, pp. 50-56. DOI: 10.1016/j.jpowsour.2014.02.103

[12] Conte M., Graditi G., Ippolito M.G., Riva Sanseverino E., Telaretti E., Zizzo G. (2011). Analisi e definizione di strategie di gestione e controllo di sistemi di accumulo elettrico per applicazioni in reti di distribuzione attive automatizzate, Report $\mathrm{RdS} / 2011 / 303$.

[13] Saft. Lithium-ion battery life, from www.saftbatteries.com accessed on 22 August. 2017.

[14] Evola G., Margani G. (2016). Renovation of apartment blocks with BIPV: Energy and economic valuation in temperate climate, Energy and Build, Vol. 130, pp.794810. DOI: $10.1016 /$ j.enbuild.2016.08.085

[15] Tina G.M., Gagliano A. (2016). An improved multilayer thermal model for photovoltaic modules, Proc. of Computer and Energy Science (SpliTech), International Multidisciplinary Conference on, Split, pp. 1-6.

[16] Alonso Garcia M.C., Balenzategui J.L. (2004). Estimation of photovoltaic module yearly temperature and performance based on Nominal Operation Cell Temperature calculations, Renew. Energy, Vol. 29, pp. 1997-2010. DOI: 10.1016/j.renene.2004.03.010

[17] Skoplaki E., Palyvos J.A. (2008). On the temperature dependence of photovoltaic module electrical performance: a review of efficiency/power correlations, Sol.Energy, Vol. 83, pp. 614-624. DOI: 10.1016/j.solener.2008.10.008 
[18] Barsali S., Di Marco P., Filippeschi S., Franco A., Giglioli R., Poli D., Dimostratore di casa attiva, Report Enea RdS/2011/307.

[19] Volpi N. (2014). SEU ed Accumulo Residenziale: nuove opportunità di business. M.S. thesis, Department of Industrial Engineering, Padova University, Padova, Italy.

[20] Weniger J., Tjaden T., Quaschning V. (2014). Sizing of residential PV battery systems, Energy Procedia, Vol. 46, pp.78-87. DOI: 10.1016/j.egypro.2014.01.160

[21] Lo Cascio E., Ma Z., Borelli D., Schenone C. (2017). Residential building retrofit through numerical simulation: a case study, Energy Procedia, Vol. 111, pp. 91-100. DOI: 10.1016/j.egypro.2017.03.011

[22] Gagliano A., Patania F., Nocera F., Capizzi A., Galesi A. (2013). GIS-based decision support for solar photovoltaic planning in urban environment, Sustainability in Energy and Buildings, Vol. 22, pp. 865-874. DOI: 10.1007/978-3-642-36645-1 77

[23] Mazzeo D., Matera N., Bevilacqua P., Arcuri N. (2015). Energy and economic analysis of solar photovoltaic plants located at the University of Calabria, International Journal of Heat and Technology, Vol. 33, pp. 41-50. DOI: 10.18280/ijht.330406

[24] European Commission, Joint Research Centre - PVGIS, from http://re.jrc.ec.europa.eu/pvgis/ accessed on 22 August. 2017

\section{NOMENCLATURE}

$\begin{array}{ll}\text { A } & \text { net surface area, }\left(\mathrm{m}^{-2}\right) \\ \text { DOD } & \text { Depth of Discharge }(\%)\end{array}$

\section{E}

G

Dss

$P$

Rsc

SOC

$\mathrm{t}$

$\mathrm{T}$

\section{Greek symbols}

$\alpha$
$\beta$
$\eta$
$\mu$
$\tau$
$\tau \mathrm{V}$

\section{Subscripts}

$\mathrm{ch}$

ds

EES

grid-exp

grid-imp

h-load

inv

$\mathrm{m}$

NOCT

PV

$\mathrm{Sc}$

STC
Energy (kWh)

Solar Irradiation, $\left(\mathrm{kWh} / \cdot \mathrm{m}^{-2}\right)$ degree of self-sufficiency (-) power, W

realised self-consumption rate (-),

State of Charge; $(\%)$

time lapse, $h$

Temperature $\left({ }^{\circ} \mathrm{C}\right)$

Solar absorptance (-)

Tilt angle (degree)

efficiency, -

Temperature coefficient $\left(\% /{ }^{\circ} \mathrm{C}\right)$

time (hour)

Solar transmittance (-)

charged

discarged

electricity energy storage

exported to the grid

Imported by the grid

house electric load

Inverter

Mismatch

Nominal operating cell temperature

photovoltaic

Self-consumption

Standard test conditions 